\title{
Palavras, silêncios e entrelinhas In memoriam de Jaime Salazar Sampaio ${ }^{1}$
}

\author{
Sebastiana Fadda
}

Apesar de ser uma acção insensata, por ser inevitável e flagrantemente inconcludente, nem sempre conseguimos resistir à tentação de imaginar outras realidades, situações, acontecimentos. Esta afirmação não aponta,

evidentemente, para os universos criativos produzidos por aquela que se convencionou designar com o termo "arte", mas para as pequenas realidades, ou banalidades, quotidianas, com o seu infinito leque de combinações, que podem surgir a partir dos chamados "periodos hipotéticos das possibilidades". Isto é: a hipótese é apresentada apenas como possivel, porque o facto poderia suceder, ou não. Mais em concreto, vejamos uma frase, como por exemplo:

"Se estivesse entre nós, aqui e agora, Jaime Salazar Sampaio, como reagiria?"

Sabemos, porém, que esta hipótese, admissivel gramaticalmente, é inviável factualmente. Isso não impede que a hipótese seja colocada e que a imaginação complete a situação sugerida com base numa "previsibilidade comportamental" do referente, ou do referido, em causa. António Braz Teixeira deu dele uma definição certeira e lapidar, ao chamar-Ihe "um pessimista bemhumorado", expressão que muito divertia o retratado. Suponho não estar demasiado longe da verdade, ao imaginá-lo aqui entre nós, alegre e excitado, talvez quase feliz, por certo, mas muito desconfiado e, fazendo jus ao amigo filósofo, desabafar corrosivamente: "Estão a querer enterrar-me."

Bem dificil, para quem com ele privou...

E como deixar de imaginar que agora, desse outro lado da realidade em que se encontra, ele, que desconfiava de homenagens, possa sufocar a exclamação: "Estão a querer desenterrar-me."

Tão acostumado, durante os anos da ditadura, à indiferença ou até à hostilidade do meio, Jaime Salazar Sampaio nunca conseguiu lidar pacificamente com o manifesto apreço de que teve muitos testemunhos ao longo duma carreira feita de talento e originalidade, rigor e persistência. Apenas perante muitas provas dadas rendiase - ou resignava-se - à evidência, e então, tal como era persistente na dedicação à escrita, tornava-se persistente nos afectos. Se nos tivesse honrado com a sua confiança, teria sido o nosso fim: nunca mais nos teriamos livrado dele... nem ele de nós.

Para o recordarmos hoje, proponho um roteiro que repercorre algumas etapas editoriais e pistas de leitura da sua obra abordando traços de uma bio-bibliografia - de uma auto-apresentação, de uma dramaturgia, de um retrato a várias mãos - e uma despedida provisória.

\section{1 - Traços duma biobibliografia.}

Jaime Augusto Salazar Sampaio (Lisboa, 5 de Maio de 1925) estreia-se na escrita com a peça Aproximação, editada em 1945 na antologia de vários autores Bloco $1^{a}$ pedra, logo apreendida pela censura. Entre 1949 e 1960 dedica-se à poesia e à narrativa - de tom surreal e existencialista - que edita em cinco volumes: Em rodagem, Poemas propostos, O romance de uma rosa verde, Palavras para um livro de versos, 0 silêncio de um homem e 0 ramal de Sintra. De poesia, são também O viajante imóvel (1977), O mar não precisa de poetas (1998) e a antologia As primeiras palavras foram de amor (2007), organizada por Luis Valente Rosa.

Mas afirma-se, de facto, como dramaturgo, aproximado com frequência aos cultores de um teatro do absurdo lusitano que tentavam inserir elementos de protesto mais ou menos cifrados a fim de ultrapassar a barreira censória erguida pelo regime salazarista. Motivações e mal-estar no plano social e político entrelaçam-se com as ansiedades existenciais das suas personagens, caracterizadas pela solidão, pelo desespero e pela desconfiança no poder de salvação de dogmas e ideologias. São estes os traços constantes quase da totalidade de uma produção intrigante e cheia de subentendidos. Não é por acaso que Strindberg, Pirandello, Pessoa e Beckett surgem entre os autores de eleição de Salazar Sampaio e que influenciam aquela espécie de "teatro de câmara" (Paniágua 1974: 241), intimo e intimista que o distinguem.

Em 1974 regista-se uma breve fase orientada para a crítica social mais activa, solicitada pelas circunstâncias históricas que o país está a viver, e de que resultam Nesta hora grave, A inauguração da estátua, Os preços e Árvores, verdes árvores. Enquanto os anos 80 marcam o regresso às atmosferas dos textos de estreia, nos tempos mais recentes volta a espreitar, ou, por vezes, a ter uma presença mais incisiva e explícita, uma atitude crítica.

A sua fecunda actividade inclui até hoje cerca de sete dezenas de peças, na maioria já levadas à cena, reunidas em cinco volumes pela Imprensa Nacional - Casa da Moeda, sob o título Teatro completo (1997-2010). Entre as peças mais emblemáticas e representativas da sua produção, destacam-se: 0 pescador à linha, Nos jardins do Alto Maior, Conceição ou um crime perfeito, Junto ao poço, Os visigodos, A batalha naval, O desconcerto, Fernando (talvez) Pessoa, Rosas e aplausos para Isabel, O meu irmão Augusto, Arraial, arraial, Aqui. De passagem... Um homem dividido, A inclita geração, A escolha acertada. Em 2008 saiu também o volume Lanterna mágica, que 
Jaime Salazar Sampaio, Raul Solnado e Carlos Avilez na SPA a 20 de Maio de 2005
Fabrice Schurmans, Jaime Salazar Sampaio, José Jorge Letria e Carlos Paniágua na SPA a 30 de Maio de 2005. contém peças curtas e "encurtadas", ou seja, com cenas extraídas de peças já editadas e que aqui ganham autonomia.

Constante, a partir dos anos sessenta, é também a sua actividade de tradutor de teatro, desempenhada por vezes em parceria com outros autores, de que resultam versões em português de peças de Beckett, A. Miller, Obaldia, Arrabal, Pinter, Joyce, Fuggard, G.B. Shaw, Genet, Albee e Finn Junker, entre outros. Foi também co-redactor de sete antologias literária destinadas ao ensino secundário e de vários artigos sobre o ofício de dramaturgo.

\section{2 - Traços duma auto-apresentação. ${ }^{2}$}

Em 2006, por iniciativa da Sociedade Portuguesa de Autores, na pessoa de José Jorge Letria, e em parceria com as Publicações D. Quixote, saiu uma fotobiografia, que tive a honra de organizar. Numa entrevista aí incluída, o dramaturgo, longa e devidamente espicaçado, foi abrindo o jogo, com reticências e perplexidades, sobre as suas lides literárias. Na verdade, foi uma espécie de tortura recíproca, sobre a qual posteriormente manteriamos um silêncio digno, mas que poderia traduzir-se com esta imagem: a entrevistadora a morder sem querer largar a perna, e o entrevistado a sacudi-la para ver se conseguia livrar-se dela e pôr-se a milhas..

Ficou-se assim a saber que, em 1940, o "menino" Jaime Salazar Sampaio concorreu "aos Jogos Florais Infantis da Emissora Nacional ("Maçadora Nacional", como se dizia...)" e obteve "duas valentes menções honrosas". Duas! Uma delas para esta quadra:

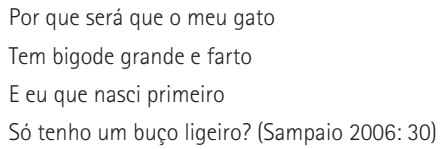

Talento precoce, como se pode verificar, pois aí já se intuia a costela absurdista que maior desenvolvimento teria mais tarde, e conotada, entre outros aspectos, pela inabalável teimosia em fazer perguntas destinadas a ficarem
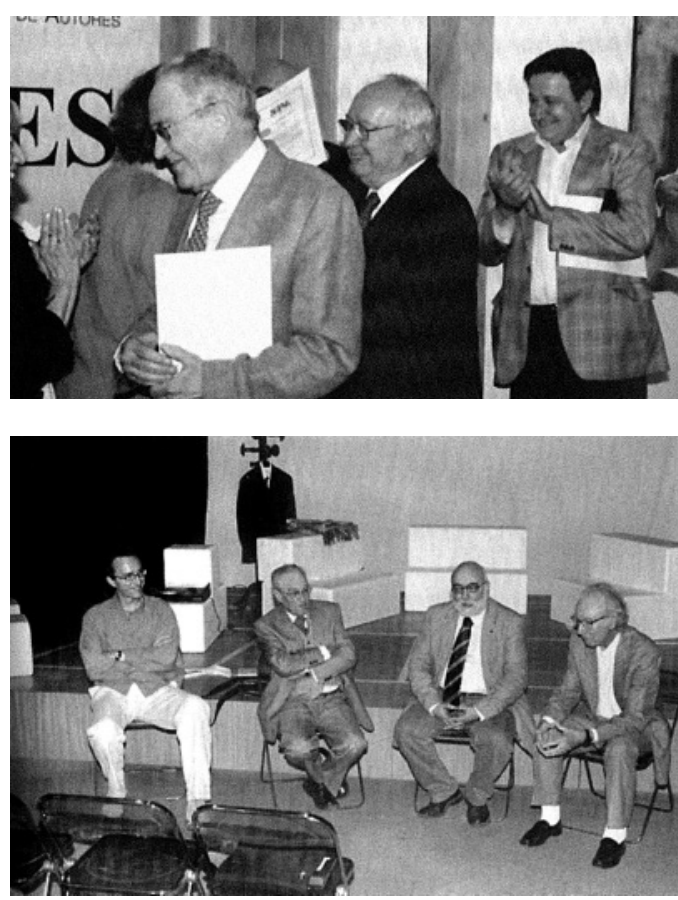

insatisfeitas. 0 que aconteceu nessa circunstância recordada, foi que nem o gato, armado duma teimosia igual ou até superior à do seu interlocutor, nem o júri, que atribuiu o prémio, souberam resolver o enigma. E o adolescente, manteve-se firme na sua postura, nunca desistindo das perguntas, que aliás se multiplicaram, crescendo em poder corrosivo e saborosa ironia.

Facécias à parte, na origem da escrita de Jaime Salazar Sampaio, estiveram dois poderosos impulsos: a necessidade de comunicar e o prazer de criar, rodeados de um halo mágico e misterioso, que de algum modo escaparia ao controlo do criador... segundo este último. Na verdade, uma extrema exigência estava sempre subjacente à sua escrita depurada, mesmo que o autor mal assumisse a sua condição de dramaturgo profissional ou a adopção de uma metodologia de escrita. Inquirido a este respeito, respondeu:

Metodologia, eu?... Não me parece. É um conceito demasiado solene para as minhas posses. 0 que eu tenho, isso sim, é uma certa maneira de esperar que as peças me aconteçam. (...) Geralmente as coisas passam-se desta maneira: primeiro há um espaço, com determinadas características, que vem ter comigo, vindo não sei de onde. E nesse espaço (...) há um ou mais vultos a deambular. São os aspirantes à categoria de "personagens". Também eles surgiram, como por encanto. Ou então - sei lá! - já andavam comigo de braço dado, sem eu dar por isso. Por agora, tais vultos ou estão caladinhos ou falam muito pouco. Mas arrumam-se no espaço, à sua maneira, medindo a distância que os separa uns dos outros. (Ibid: 32)

Claro que convinha fingir acreditar nesse mistério, aliás deliberado e procurado. Isto é, era um acto voluntário e consciente, tal como o próprio dramaturgo mais tarde se apressou a esclarecer, como que sem dar por isso:

(...) no dia 17 de Maio do ano corrente de 2005 - comecei a avançar com a hipótese de uma nova peça. E nesse dia - de madrugada como é habitual - fui assaltado por certas imagens, definindo um espaço (...) e três vultos, todos masculinos. (...) Tinha ao meu dispor muitos 


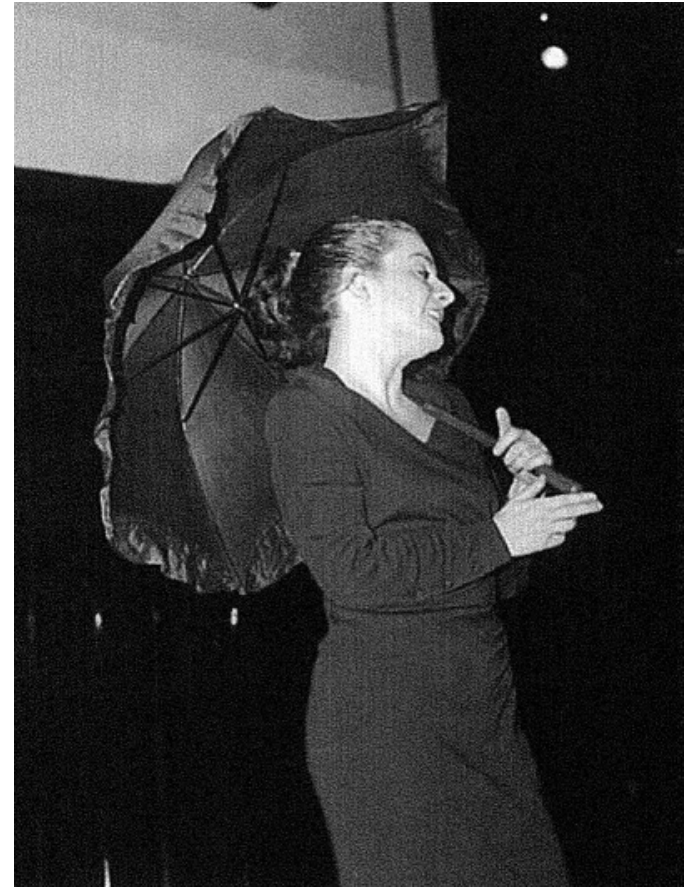

pormenores e algumas lacunas; perdão: alguns pormenores e muitas lacunas. (...) Vejamos o que eu de momento sei, ou julgo saber desta experiência. (Ibid: 33)

Acerca do espaço cénico opinava:

Deverá ter uma certa profundidade. Em condições ideais, será mesmo (...) bastante profundo. As paredes laterais, em ruinas, exibem grandes buracos, em parte obstruidos por um amontoado de detritos, de diversa natureza. Quanto à parede do fundo, apresenta uma superficie irregular e, perto dela, há cacos de espelho. (...) 0 que teria acontecido, naquele espaço e à volta dele, antes de a peça ter começado? (Ibid: 33-34)

E acerca dos três vultos masculinos:

\begin{abstract}
Não sei ainda os seus nomes, mas já conheço as suas alcunhas: Enferrujado, Hesitante e Fala-Barato. Talvez nem precise de vir a conhecer propriamente os seus nomes de baptismo; mas uns diminutivos faziam-me jeito. Falta saber quais... Zé? Zé-Zé? Tó Zé?... Podem ser estes mas é bem possivel arranjarmos outros. 0 que é necessário é que tenham uma valente raiz comum; quase tirados a papel quimico. (Ibid: 34$)$
\end{abstract}

Estes trechos referiam-se à peça Agora e mostramnos um dramaturgo de raiz, meticuloso, conhecedor do espaço e dos ritmos cénicos, de olhar treinado e próximo do do encenador experiente, tal como se inferia das abundantes didascálias, pelo apurado labor artesanal com que todo o supérfluo era retirado, ficando apenas os elementos indispensáveis. A presumida falta de metodologia era afinal uma imaginação encenada, que o dramaturgo insistia em apelidar "uma certa maneira de esperar que as peças me aconteçam". E em comum as peças tinham as características seguintes:

Lentidão da escrita. (...) Passagem da escrita a duas dimensões (as do papel) para o esboço, a três dimensões, de um imaginário local cénico. (...) Título da peça e nomes dos personagens. (...) Perfil das personagens. (...) As personagens e o mundo exterior. (Ibid: 42-43)

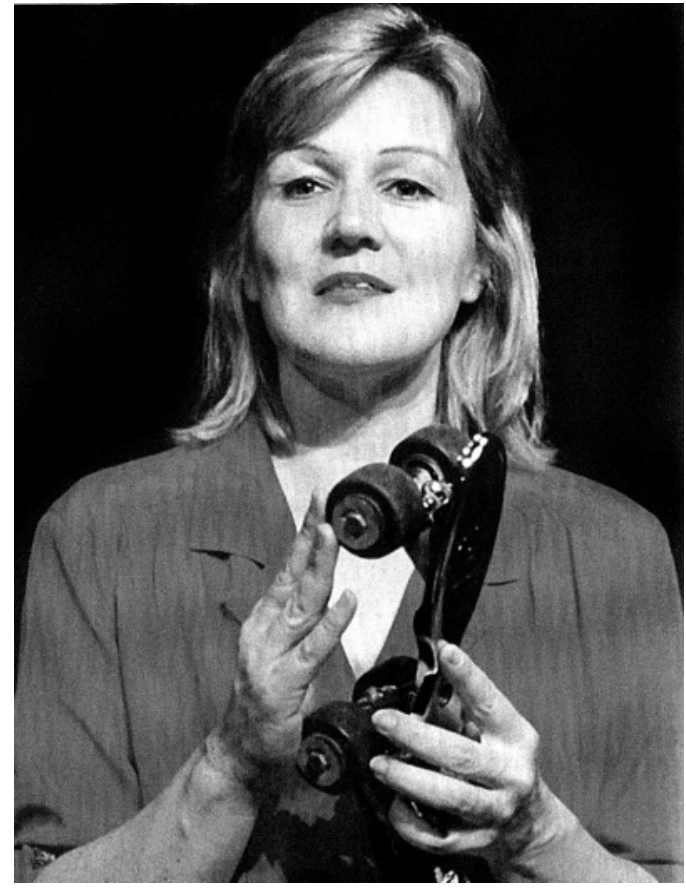

Magdalena, enc. Jaime Salazar Sampaio, Teatro da Malaposta, (Matilde Cañamero) 1991.

Magdalena, enc. George Ritchie, Lisboa, Estrela Hall, (Amanda Booth) 1997.

Até ao 25 de Abril de 1974, o autor escrevia tendo sempre presente a Censura, que iria avaliar a peça, tendo o poder de decidir do seu destino posterior. Para contornar o organismo censório, tornou-se necessária a adopção duma estratégia específica, que se transformou numa técnica pessoalissima:

0 jogo era este: um jogo de espertezas e de compromissos. Primeira regra - certos assuntos... nem pensar enfiá-los numa peça! Segunda regra - começando por escolher um assunto que não incomodasse (...) era

aconselhável ter um outro cuidado: quando eu queria dizer uma coisa que sabia não poder

nomear, referia-a... por um outro nome. E se fosse preciso, acrescentava uma poeira de palavras "descomprometidas", tentando criar um clima de ambiguidades.

0 pior é que, por culpa destes malabarismos que eu me sentia obrigado a praticar, a pouco e pouco (...), a auto-censura tomou conta de mim, como se eu fosse, ou tentasse ser, um auxiliar da tal Comissão. (...)

E a jogatana tornou-se um vicio. Muito embora esse vicio, para além de ter certas consequências desfavoráveis, tivesse também uma inesperada virtude: ao empurrar o essencial do discurso para as entrelinhas - e era esta uma das regras mais importantes daquele jogo - eu estava a aprender o meu oficio de escriba, já que o essencial nem sempre se pode verbalizar, cabendo ao silêncio das entrelinhas sinalizá-lo; de forma subtil, se formos capazes... (Ibid: 51)

Tendo o incentivo de Artur Ramos, as coisas correm relativamente bem, apesar de percalços como a proibição de Nos jardins do Alto Maior, o fracasso de Os visigodos e o êxito de Batalha naval. Mas o cenário e o registo mudam, temporariamente, depois do 25 de Abril. Surgem os desafios de Carlos Paniágua, que terão como resultado A inauguração da estátua:

[P]or diversas razões, escrever e acompanhar a subida à cena de $A$ inauguração da estátua foi para mim uma experiência única e inesquecivel, vivida com entusiasmo (...). Nos dez dias em que 
percorremos o distrito de Bragança demos espectáculos em pequenas povoações e ai encontrámos uma espontânea e comovedora identificação entre a cena e o público. Isso fez-nos acreditar que, às vezes, o teatro vale mesmo a pena. (Ibid: 54 )

Parêntesis passageiro, o da escrita sem reticências, que em breve deixaria o lugar ao anterior jogo às escondidas e à defesa, tornando-se a ambiguidade já não um meio para escapar a censuras, mas a peculiaridade duma escrita densa de ressonâncias e de sentidos múltiplos. E a partir dos anos 70, a subida à cena de peças do autor tem sido regular, e com encenadores reincidentes: os já referidos Artur Ramos e Carlos Paniágua, a quem se juntam mais tarde José Martins, Rogério de Carvalho, José Mascarenhas, Fernando Oliveira, João Lázaro e Joaquim Guerreiro, entre outros. E quanto mais nos aproximarmos dos nossos dias, mais as personagens típicas do autor alternam com personagens atípicas, preocupadas com a sociedade em que, melhor ou pior, quer queiram quer não, estão integradas. Estas excepções, de início mais esporádicas, a certa altura circunstanciais, nos últimos tempos com uma certa regularidade, apontam para um maior empenhamento, ou pelo menos para um posicionamento mais declarado do autor. E tal como no caso dos encenadores, houve editores reincidentes: Plátano, Hugin Sociedade Portuguesa de Autores e Imprensa Nacional. É a esta última, e ao impulsionamento ímpar na divulgação do teatro que soube imprimir a direcção esclarecida de António Braz Teixeira, que o próprio autor reconheceu a responsabilidade, e o mérito, da existência da produção mais recente.

Em teatro, dizia o autor, "a melhor das regras é não haver nenhuma", deixando assim aberto o espaço para a confluência de várias contribuições da parte de todos os elementos envolvidos no processo de criação de um espectáculo. Porque Jaime Salazar Sampaio, como o seu percurso emblematicamente testemunha, sabia que o teatro é uma arte colectiva, em que o autor aprende com os encenadores e estes com aquele, mas sem nunca abdicar da responsabilidade que, enquanto dramaturgo e na sua opinião, the cabia de fazer o seu trabalho de casa, ajudando o encenador a enquadrar o seu pensamento num espaço cénico concreto. Mas já ele, enquanto autor, sempre escreveu para um espaço concreto e para corpos reais, não apenas para simples emissores de conceitos alheios. Bem o viram Mário Sério e Carlos Porto, em 1984, ao dar o título das suas recensões ao espectáculo Magdalena, respectivamente, "Saber honrar o corpo" e "Magdalena sem Maria", porque é pela palavra que as coisas se nomeiam, mas é na celebração e derrota da matéria feita carne que a vida se abastece a si própria.

Se o dramaturgo deve fornecer um roteiro ao encenador, este, no entender deste autor, tem uma tarefa que anda próxima da do tradutor. Haverá graus de cumplicidade e entendimento variáveis, que determinam vários graus de proximidade. As subjectividades e as
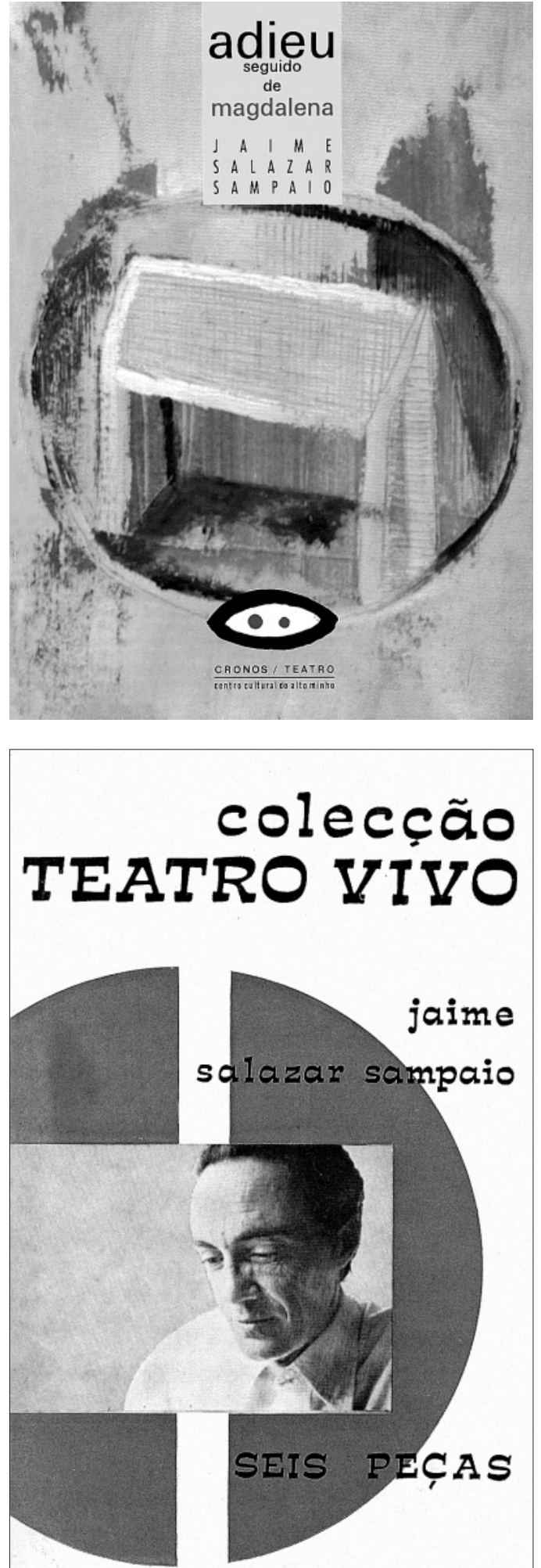

(5)
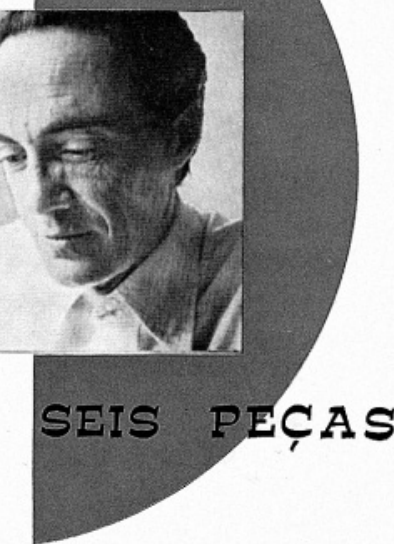

Plátano Editora

contingências, sujeitas à eterna lei da mutabilidade, fará com que cada paisagem seja única, irrepetivel e permanentemente inacabada. Esta consciência acompanhava o processo de trabalho de Jaime Salazar Sampaio, sempre zeloso com o todo e com os pormenores que o constituiam. Mas à posição quase intransigente que assumia com ele mesmo, contrapunha-se uma democrática maleabilidade, quando se tratava de colaborar de forma 


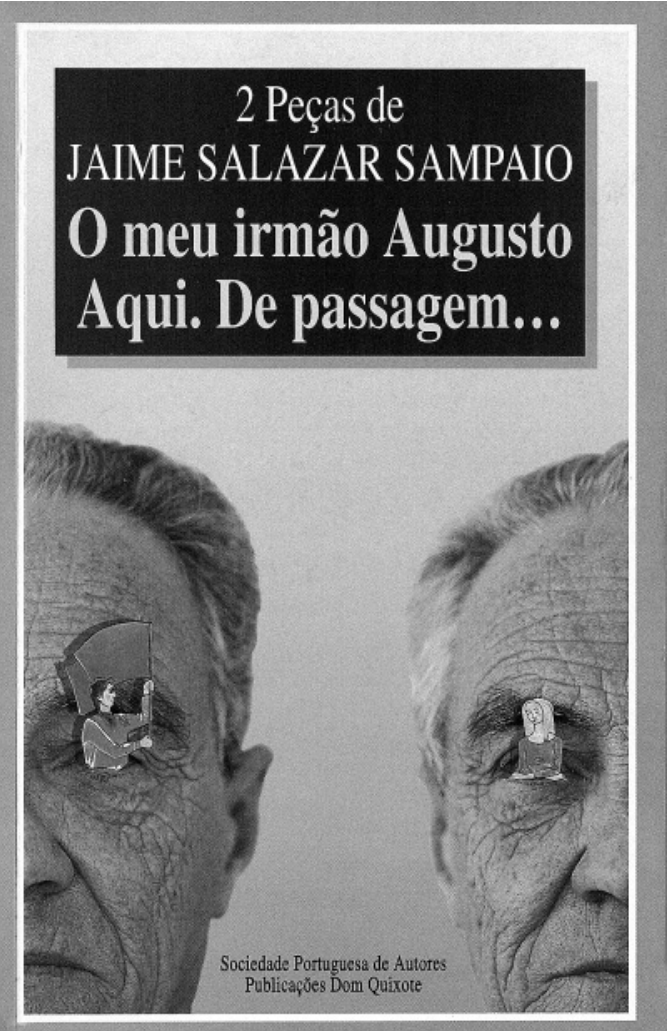

mais directa no processo de criação dum espectáculo. Isto é, quando surgiam as encomendas. Nesse caso conjugava 0 interesse e o prazer pessoais com as condições que iriam acolher o novo texto. Sem recorrer a receitas ou fórmulas pré-formatadas:

No convivio entre dramaturgos e encenadores, a única regra, penso eu, é não haver nenhuma. Cada caso é um caso. E o mais são histórias (...) escrever peças e levá-las à cena, sempre foi e será uma aventura de todos os diabos, plena de riscos e de surpresas. À partida dizemos: como fazer? E quando o trabalho estiver acabado, convém enfrentar uma outra interrogação: teriamos feito as coisas da melhor maneira?

Onde há riscos, pode haver erros. (Ibid: 76)

E quando o dramaturgo vestiu a pele do encenador, coincidência que se deu com Junto ao poço e Magdalena a cena exibiu mais uma vez a sua instabilidade, e o principio da relatividade impunha-se sobre as verdades absolutas, levando às conclusões habituais: não há regras universalmente válidas; numa avaliação a priori, a medição dos elementos e das forças em jogo mostra que o seu relacionamento pode ser conflitual, pelo que o poder de mediação se torna fundamental; numa avaliação $a$ posteriori, as soluções a que se chegou poderão não ter sido as mais felizes, mas talvez tenham sido as melhores possiveis naquela determinada circunstância. Depreendiase, então, que o convivio com o palco devia transformar o dramaturgo num malabarista a quem convinha saber andar numa corda bamba, caso contrário teria todas as probabilidades de se estatelar no chão... Bastava aceitar correr o risco, não se levando demasiado a sério, ou assim fingindo que fosse. Em contrapartida, o jogo do faz-deconta teria dado continuidade à ironia poética do jogo floral ganho na adolescência, tornando-se viagem e procura:

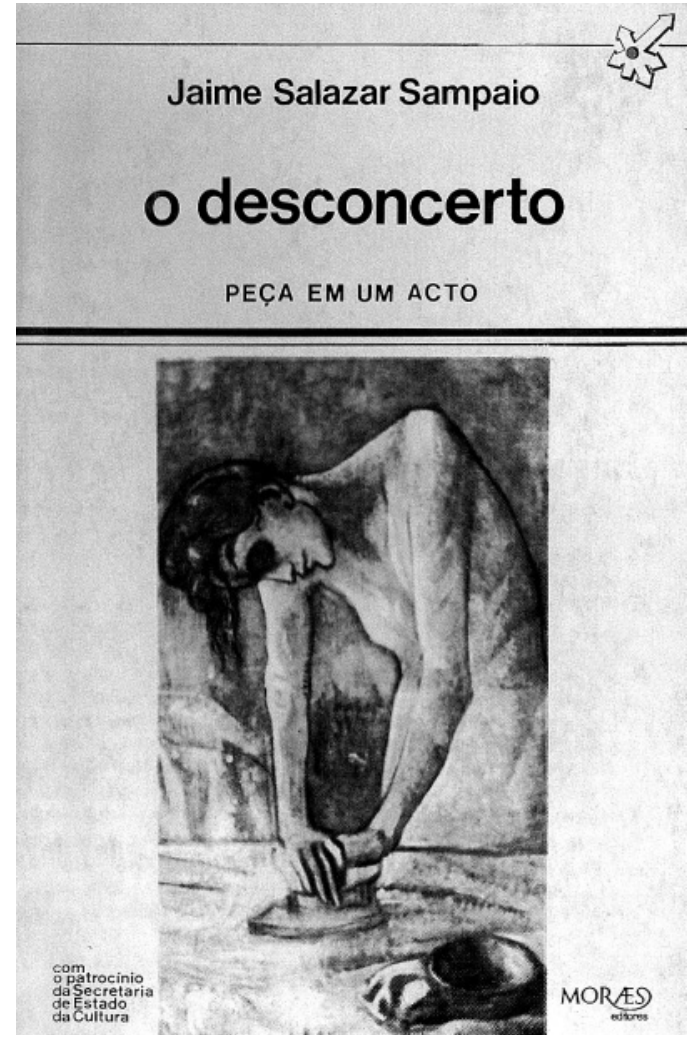

Capas de livros

0 teatro é o local onde encontro melhores condições para perguntar quem sou. (...) E são as personagens que me servem de cobaia. Ponho em cada uma delas um bocado de mim (...) e fico à espreita, a ver como elas, ao longo da fábula, se desembrulham. Será isto o que se chama, com todo o desprezo, "contemplar o umbigo"? Ou, pelo contrário, é a única maneira que eu tenho de me aproximar dos outros tripulantes da mesma jangada, que deambulam como eu, pelo alto mar?

Quem souber responda. (Ibid: 84 )

Quanto a balanços, a conclusão seria lapidar: "Foi tudo inútil, mas valeu a pena."

\section{3 - Traços duma dramaturgia. ${ }^{3}$}

Apesar de Salazar Sampaio afirmar a insuficiência da palavra como meio de comunicação, a verdade é que prescindir dela, quer como dramaturgo, quer como observador do seu próprio processo de escrita, invalidaria o estatuto que the circulava no sangue.

Na sua dramaturgia, qualquer leitor pode detectar a tendência para a reiteração dos elementos que compõem os seus textos-mosaicos. Mas a aspiração a escrever certos silêncios foi tão poderosa como o impulso para transmitir conteúdos, ou apelos lançados em versos, deixas,

didascálias, telegramas, cartas, garrafas atiradas ao mar.

0 substrato existencialista é inequivoco e visivel. As personagens (os seres humanos) vivendo sofrem e sofrem porque vivem. Isoladas à superfície e na profundidade, descobrem a falta de soluções, a existência de limites como um mal irreversível, a incapacidade de aceitação dos limites como um dos sintomas do mal. A busca frustrada do paraíso perdido, na falta de amor e solidariedade, procura a saída no jogo trágico, no fazer de conta que o breve intervalo de uma existência tem sentido e que tudo vale a pena ser vivido, como se

Este parágrafo reconfigura excertos dum ensaio mais extenso editado em Portugal (Fadda 2003: 15-22) 


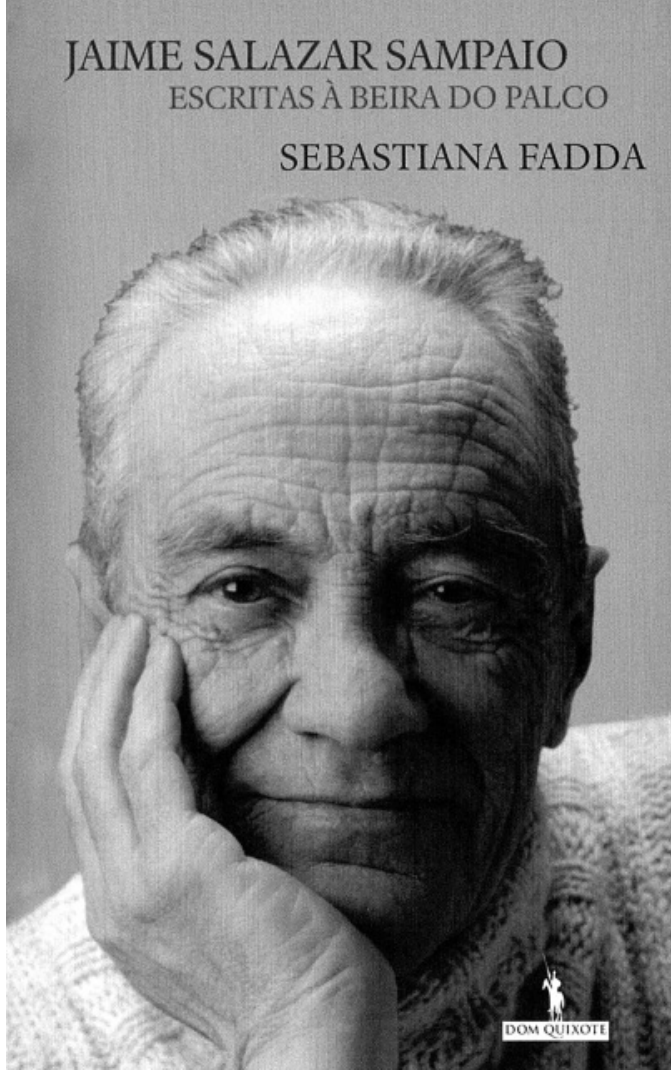

"eternidade" não fosse uma palavra estéril, e "solução" oferecesse uma hipótese decisiva.

Eros e Thanatos, temas omnipresentes, desenvolvidos ao falar de amor, ou da falta dele, sepultado antes de começar, ou seja antes da morte. E no relacionamento Amor-Morte, a segunda prevalece, impondo a falta de lógica e de sentido do amor e da vida.

A função do espelho, um dos adereços recorrentes no espaço cénico do autor, é dúplice, sendo elemento para reflectir e lugar de auto-reflexão por excelência. Quando ausente, as suas alomorfias são a água e as vidraças. A água - com a sua carga simbólica de desejo de protecção, de retorno ao ventre materno e ao estado pré-natal adquire uma dupla valência. A nível inconsciente é o refúgio escolhido pelos protagonistas para se preservarem do sofrimento, o líquido amniótico do estado fetal, o colo da primeira infância. A nível consciente é o símbolo da barreira que separa o indivíduo do ambiente que o rodeia em que se desloca como judeu errante ou permanece imóvel como uma ilha num arquipélago rarefeito.

Dai o desejo de fuga, manifestado pelas viagens constantes, múltiplas, paralelas, cruzadas, contrapostas, em espiral, nunca lineares. A primeira viagem é através e na profundidade das coisas que se abrem e revelam, tal como caixas chinesas; a segunda, efectuada ainda a partir dos objectos, é na abertura das caixas chinesas da interioridade, num tempo cristalizado.

Viajantes do tempo, de mala na mão ou à vista, as personagens estão rodeadas por fantasmas, pouco importa se fictícios ou não, pois se nem tudo o que com eles se passa talvez seja verdadeiro, tudo existe enquanto a mente o produz ou a memória o evoca: ecos de guerras e torturas; fanatismos geradores da intolerância; preconceitos que é preciso combater em nome do pluralismo pacífico; formas de vida podre, que não passam de aparências de vida; cadáveres invisíveis e corpos vivos apesar de o homicídio já ter sido consumado; crimes não puniveis devido à ausência de cadáveres, apesar de não ser necessário encontrar cadáveres para provar crimes realmente cometidos; solidão que não chegou a ser solidária; acusações mudas de falta de compaixão e indiferença a uma ética humanística.

Espelhos, malas, armas e relógios são objectos que é raro faltarem no palco de Jaime Salazar Sampaio, como habitual é a inserção de referências culturais, bíblicas, pessoais e teatrais, de auto-citações na transumância de elementos que transitam de uma peça para outra (conflitos, nomes, adereços, excertos de versos e cenas).

Enigmática, fantasiosa e ambígua, a obra de Jaime Salazar Sampaio afirma-se como desafio, lançado pelo autor a si próprio e ao leitor / público, e reivindica o direito de abrir e desencadear conflitos a partir das ir/realidades mais variadas e dos fragmentos delas. A vida (o teatro) não se limita ao mundo evidente (ou a sentidos unívocos), mas pode ocultar-se por trás das aparências, sem que isso signifique defesa da (auto)mistificação. 0 oposto também
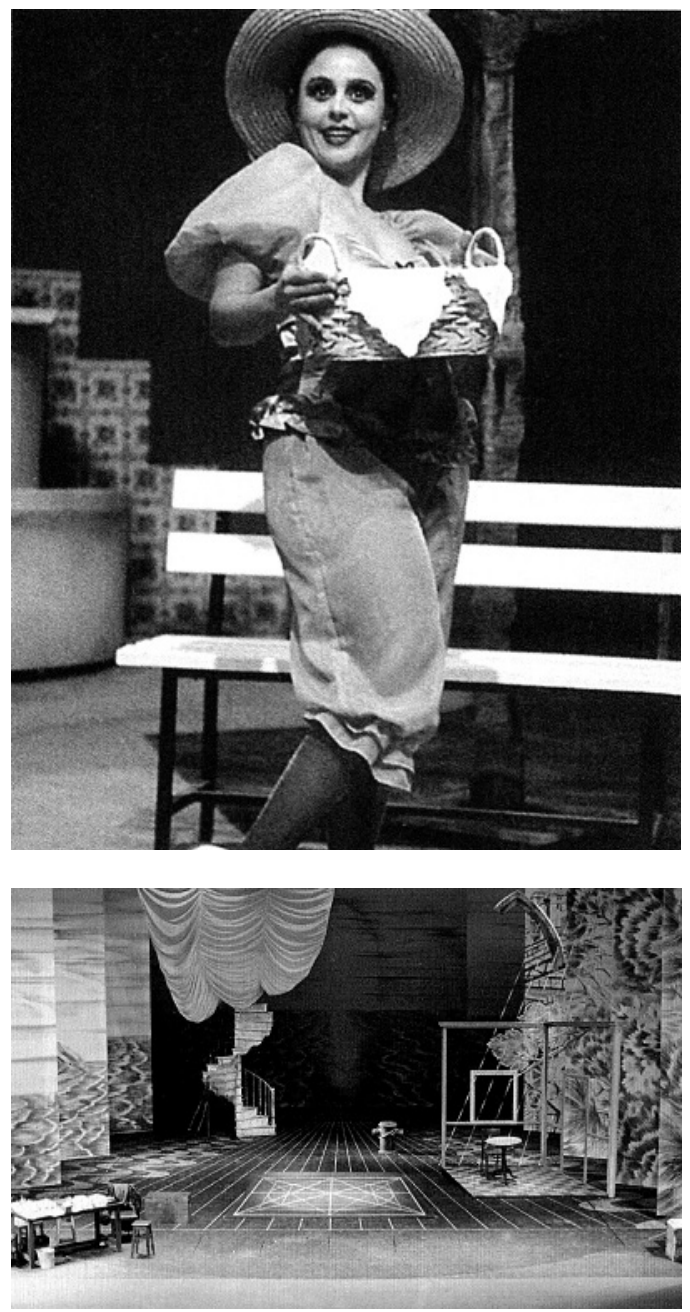

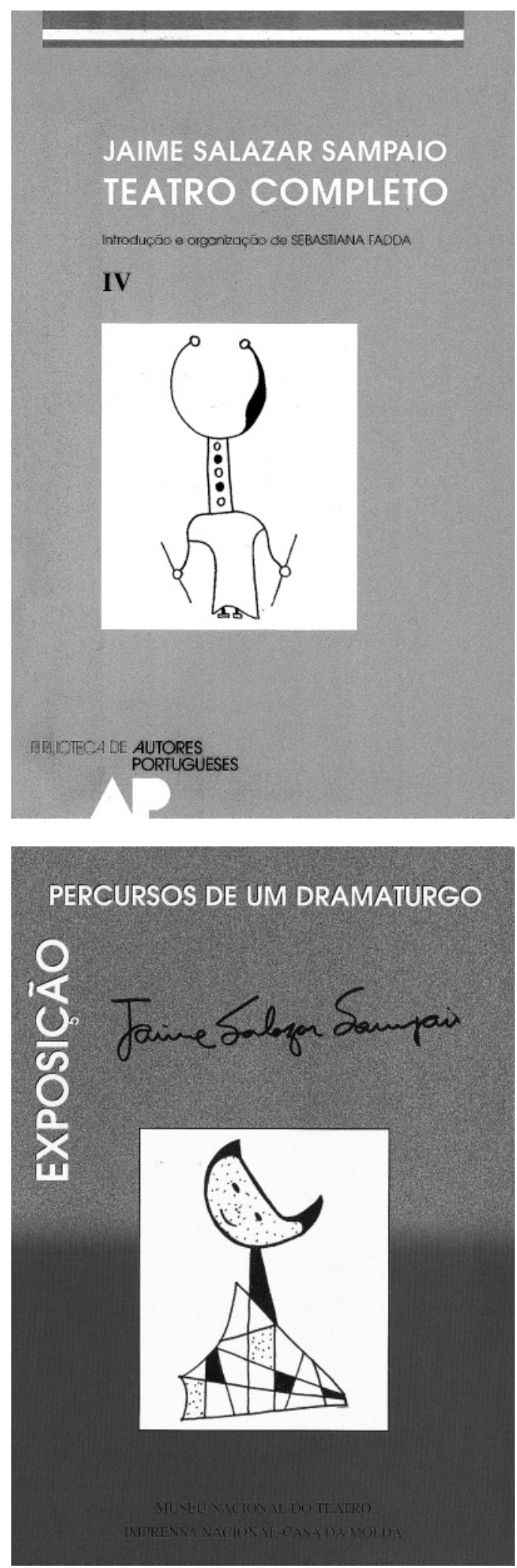

é admissivel, ou seja, por trás da sintaxe das metáforas, e por seu intermédio, definem-se os mapas do concreto.

Sintese entre teatro do absurdo, comédias de enganos, dramas grotescos de actualidade, onde se fala de vida, mesmo pela negativa, onde dela se faz o balanço e se deixam tirar lições, pela via contrária. Caminhos percorridos com personagens-viajantes em busca de equilibrio e de justiça, ou do silêncio, espalhando o que dele se alcança.
Palavras, por vezes, como sucedâneos, sublimações ou resíduos de gestos.

\section{4 - Traços dum retrato a várias mãos}

Nenhum homem é uma ilha, pelo que Jaime Salazar Sampaio foi sensivel às apreciações feitas pelos seus pares. Mesmo quando estes levantavam uma voz crítica, e não apenas laudatória, dela fazia matéria de reflexão que alimentava os seus periódicos balanços. Daí que os olhares exteriores, os depoimentos e testemunhos que os profissionais de espectáculo e da cultura foram dando ao longo de mais de 60 anos de actividade do autor acompanharam o percurso do homem e da obra.

"Vidas paralelas" foram as de Jaime Salazar Sampaio e Luiz Pacheco, que registou alguns episódios saborosos:

Conheci o Jaime muito cedo. Andou comigo no Liceu Camões,

nunca na mesma turma, já nos anos 1935-36 (...) sempre foi muito reservado, é o feitio dele (...) Em rodagem, o primeiro livro de poemas de Salazar Sampaio, é um livro ligeiro. Teve uma critica muito má nas páginas da revista Vértice, assinada por um estupor que depois veio a ser ministro, um tal Armando Bacelar... Mais tarde sairam os Poemas propostos, que teve a amabilidade de me dedicar. Uns dez anos depois escreveu (...) O viajante imóvel. Era feito a partir de poemas cortados, ou seja de frases cortadas e separadas em três montinhos que depois iam sendo coladas. (...) A primeira peça, Aproximação, saiu juntamente com vários poemas na colectânea Bloco, que foi apreendida pela PVDE. (...) Os exemplares que conseguimos salvar esgotaram facilmente. Em Lisboa havia gente que estava atenta e o livro teve uma certa repercussão. (...) Eu fui à $P V D E$, pedi que cortassem o que quisessem do livro e eles responderam que não se aguentava nada, nem a capa (era muito encarnada...). (...) Até houve um pequeno episódio em que participámos, uma tentativa de desinquietar os poderes públicos. Corriam os anos Quarenta e o José Cardoso Pires organizou uma pequena acção (...) Tratava-se de lançar panfletos de protesto, do balcão e da geral do Teatro Politeama, sobre a plateia. A chuva de panfletos foi mal feita pelo Jaime e pelo Alexandre O' Neill. Eram folhas A4 e, em vez de cairem em leque, acabaram por cair todas juntas. Eu cobria outro tipo que lançava. Veio muita policia, mas ninguém foi incomodado foi mais o susto (...) Na verdade, não tínhamos vocação para revolucionários a sério. (Pacheco 2006: 155-159)

Os muitos encenadores e actores com quem trabalhou são unânimes em reconhecer as qualidades humanas e o rigor do autor em apreço. Carlos Paniágua encarna hoje a mais sólida memória de um intenso convivio artístico e pessoal, tendo enveredado por uma extraordinária "viagem na esteira do dramaturgo" há mais de quarenta anos. José Mascarenhas foi um comitente regular daquele que chamou o "[s]eu irmão mais velho". João Lázaro fala num extravasamento dos limites do palco, porque "JSS não escreve para o Teatro, escreve para o Mundo [...] sublimando a fragilidade de cada um de nós num pressentimento feito poesia em estado puro". E enquanto para José Martins é "urgente a re-leitura cénica 
dos textos de Salazar Sampaio", para Mário Primo ele conta "histórias de gente real (?) e de gente surreal, de fantasmas saídos directamente da memória daqueles ou da materialização dos seus medos e dos seus desejos mais profundos".

Glicínia Quartin, a Vanda / Rosa de Os visigodos, considera esta peça:

[P]recursora do teatro que se faz hoje: curta, enxuta, sem os rasgos emocionais tão queridos do teatro realista, mas inteligente, critica, um trabalho virado para a análise dos comportamentos. Fi-la com muito prazer, sabendo que ia desafiar as mentalidades e suscitar criticas negativas e protestos. (Quartin 2006: 173)

E é para um realismo nada convencional que nos alerta Luiz Francisco Rebello:

Sem dar por isso, e talvez até convencido do contrário, Jaime Salaza Sampaio escreve peças realistas. Não, evidentemente, peças realistas no sentido naturalistico, imediato, em que o realismo ainda continua a ser entendido entre nós (... Realista no sentido em que (...) o mundo nele descrito é, literalmente, aquele em cujo labirinto nos perdemos, onde o amor é uma aspiração a todo o instante escarnecida e negada e a justiça uma exigência inacessivel, de que nos é dado contemplar apenas a contreface grotesca, quando não sangrenta, e sofrer na carne o seu látego impiedoso. (Rebello 2006: 176)

Para Maria João Brilhante o retrato que surge é o de "um atleta", nomeadamente "um dramaturgo corredor de fundo":

Ao sufoco dos anos de repressão e censura respondeu sempre, e sobretudo após 1976, com um notável fôlego dramatúrgico, numa incansável corrida capaz de contrariar aquela antiga sentença acerca do fraco génio dramático nacional (...) Se o teatro cria imagens vivas do mundo, o de Salazar Sampaio acrescenta a essas imagens o desafio de uma voz crítica, mordaz (...) Estimulado por este nosso desconcertante mundo, o escritor deixou-se há muitos anos seduzir pelo poder que detém: o de criar figuras, inventar gestos e palavras para elas, imaginar o espaço que irão habitar no "tapete", por outras palavras, pelo poder de desempenhar o 'papel de' dramaturgo / demiurgo capaz de temperar com humor e ironia as vidas quantas vezes decepcionantes que nos cabem em sorte. (Brilhante 2006: 94, 97)

Seria pela via da "ironia paradoxal" que o autor, nas palavras de Maria Helena Serôdio, interceptaria os rumos da modernidade:

\begin{abstract}
[A] declaração de um vazio insignificante a rodear o humano (paredes meias com o absurdo que, desde os anos 50 do século $X X$, foi habitando o corpo teatral do Ocidente) e a vontade de criar laços ou relações entre as personagens. E essas relações podem ser frases banais, gestos sem sentido, agressões simbólicas, fragmentos de canções, jogos e declarações enigmáticas. A habitar esses cruzamentos de falas, gestos e acções, está o gosto da interpelação, a vontade de nos pôr a duvidar da seriedade da vida, como se o teatro fosse a máscara irónica, que nos defende da insignificância, e o diálogo o álibi de um caminhar conjunto pelos caminhos do mundo. (...) Porque ele é, de facto, um autor que se deleita na lisura dos planos inclinados, na certeza das improbabilidades, na evanescência do que se quer concreto e factual. E que activa em múltiplos planos uma "filosofia de vida" que é feita de sabedoria disfarçada de ligeireza. (Serôdio 2006: 184-186)
\end{abstract}

Já foi referido que, sem os primeiros dois volumes de Teatro completo, não teriam existido os três que lhe sucederam. António Braz Teixeira argumentou a sua defesa:

[Ả]inicial admiração pelo dramaturgo, pela eficácia da sua escrita teatral e pela verosimilhança literária dos seus diálogos, em que 0 lúcido pessimismo se harmoniza com uma ironia corrosivamente triste, veio acrescendo uma sólida amizade, sustentada na verdade humana da sua personalidade, na sua generosa e timida fragilidade, que a dúvida essencial não tolhe na activa busca de precárias e interrogativas respostas, antes alimentando uma força criadora que se exprime no fundo lírico da sua poesia e da sua escrita dramática. (Teixeira 2006: 198-199)

Colega e amigo de há muitos anos, Augusto Sobral reconheceu nele um dramaturgo constante nas adversidades, contradições e elementos da escrita, bem como na alimentação da amizade (cf. Sobral 2006: 187 193). Quanto a Georges Stobbaerts, Jaime Salazar Sampaio praticava a escrita com a mesma precisão e eficácia com que praticava as Artes do Budo:

É como se ele esticasse diferentes cordas do arco das emoções atè ao seu ponto máximo de tensão, produzindo efeitos surpreendentes testemunhando movimentos dramáticos que acertam sempre no alvo. (...) As meditações do dramaturgo são susceptiveis de descer a uma grande profundidade, procurando o fundo dos abismos, mas quando conseguem subir até à superficie rebentam iluminadas pela luz do dia. (...) É assim que ele revela o seu pensamento mais pessoal. Ou seja, um pessimismo perpassado de poesia. (Stobbaerts 2006: 194-195) 
E ainda, entre muitos outros testemunhos, José Jorge Letria falou n' "um talento de poucas falas" (Letria 2006: 129); Risoleta Pinto Pedro relevou um minimalismo formal nas peças, "mas não no alcance", porque traçam "um percurso do infinitamente pequeno ao infinitamente grande" (Pedro 2006: 164). E Ana Maria Ribeiro, atenta às evoluções duma dramaturgia que se tornou da interpelação, reconhece que são os leitores e espectadores a serem inquiridos: "somos nós [...] que nos sentimos postos em causa. Por que não há inocentes, e JSS sabe bem disso" (Ribeiro 2006: 183). E encerraria esta resenha com um excerto dum texto soberbo, assinado por Jorge Silva Melo:

Desde 0 pescador á linha, a peça de estreia de Jaime Salazar Sampaio e com certeza uma das mais bonitas peças de estreia de todo o teatro português, que sabemos que as suas personagens não fincam os pés em terra firme: deslizam entre sonhos, desequilibram-se, tropeçam, endireitam-se, surgem inesperadas, irrompem pela memória, são e não são. 0 soalho oscila sempre neste seu teatro melancólico, as portas dos armários não escondem o que se espera, as mulheres trazem outra imagem, mesmo num simples passeio, a morte pode aparecer e sobretudo a dúvida, a tremenda dúvida e a teimosia em continuar. É um teatro em menor como a música mais triste, feito de acordes imperceptiveis, onde não cabe um grito ou um terramoto: é só dessa oscilação permanente, insegura, tímida, dessa incerteza entre o que está assente e o que se derrama que se faz este teatro (...) Agridoces, estas falas incertas, este murmúrio irónico, amargo sussurro que solicita alguém, alguém que o escute, um palco em que o soalho insistentemente oscila. Mas onde o homem retoma o seu caminho, endireitando-se o mais que pode. (Melo 2006: 141143)

\section{5 - Despedida provisória}

Jaime Salazar Sampaio faleceu a 13 de Abril de 2010. Reencontrá-lo-emos, sempre que quisermos e pudermos, na sua escrita, bem como nas muitas memórias de tempos e trabalhos partilhados, de diálogos pacíficos e discussões animadas. Não procurava a perfeição, o consenso, as certezas ou as respostas. Cultivava a autocritica em permanência, por vezes bastavam-Ihe as perguntas, e sabia aceitar a imperfeição humana. Esta postura de vida norteava o literato.

A sua longa aprendizagem, por vezes solipsista, muitas vezes solitária, outras ainda em busca de algo maior do que a nossa pequenez, mas que tanto frutificou, consignaa a nós, para que dela cuidemos com o carinho, a coragem e a persistência com que ele a soube construir.

\section{Referências Bibliográficas}

BRILHANTE, Maria João (2006), "Notas soltas sobre um dramaturgo corredor de fundo", in FADDA (2006), pp. 94-97.

FADDA, Sebastiana (1998), 0 teatro do absurdo em Portugal, pref. Luiz Francisco Rebello, trad. José Colaço Barreiros, Lisboa, Cosmos, Colecção Literatura, 1998

-- (a cura di) (2001), Teatro portoghese del XX secolo, Roma, Bulzoni Editore, Biblioteca Teatrale, pp. 561-563.

-- (2003), "O silêncio segundo Salazar Sampaio", in Jaime Salazar Sampaio Percursos de um dramaturgo, Lisboa, Imprensa Nacional-Casa da Moeda, Colecção Arte e Artistas, pp. 15-22.

-- (2006), Jaime Salazar Sampaio: escritas à beira do palco, Lisboa, Sociedade Portuguesa de Autores / Publicações D. Quixote, Colecção 0 Homem e a Obra, 2006.

FĖTEIRO, Carlos Paniágua (1974), "Este teatro: uma leitura", in Jaime Salazar Sampaio, Seis peças, Lisboa, Plátano Editora, Colecção Teatro Vivo, pp. 225-241.

LETRIA, José Jorge (2006), "Um talento de poucas falas", in FADDA (2006), pp. 129-131.

MELO, Jorge Silva (2006), "O soalho oscila e o homem retoma o seu caminho incerto", in FADDA (2006), pp. 141-143.

PACHECO, Luiz (2006), "Vidas paralelas", in FADDA (2006), pp. 155-161. PEDRO, Risoleta Pinto (2006), "A propósito do IV volume de Teatro completo de Jaime Salazar Sampaio", in FADDA (2006), pp. 162-165.

QUARTIN, Glicinia (2006), "Ajuste de contas", in FADDA (2006), pp. 172174.

REBELLO, Luiz Francisco (2006), "De um ou mais realismos", in FADDA (2006), pp. 175-178.

RIBEIRO, Ana Maria (2006), "Porque não há inocentes", in FADDA(2006), pp. $179-183$

SAMPAI0, Jaime Salazar (2006), "Reflexões dialogadas" [entrevista], in FADDA (2006), pp. 21-84

SERÔDIO, Maria Helena (2006), "Testemunho admissivel: sobre Jaime Salazar Sampaio", in FADDA (2006), pp. 184-186.

SOBRAL, Augusto (2006), "Jaime Salazar Sampaio. 0 dramaturgo constante", in FADDA (2006), pp. 187-193.

STOBBAERTS, Georges (2006), "A imaginação como paradoxo", in FADDA (2006), pp. 194-195

TEIXEIRA, António Braz (2006), "Uma ironia corrosivamente triste", in FADDA (2006), pp. 196-199. 